\title{
Connectivity through ontogeny: fish population linkages among mangrove and coral reef habitats
}

\author{
David L. Jones ${ }^{1,4, *}$, John F. Walter ${ }^{2}$, Elizabeth N. Brooks ${ }^{3}$, Joseph E. Serafy ${ }^{1,2}$ \\ ${ }^{1}$ Cooperative Institute for Marine \& Atmospheric Science, Rosenstiel School, University of Miami, Miami, Florida 33149, USA \\ ${ }^{2}$ US Department of Commerce, National Oceanic and Atmospheric Administration, National Marine Fisheries Service, \\ Miami, Florida 33149, USA \\ ${ }^{3}$ US Department of Commerce, National Oceanic and Atmospheric Administration, National Marine Fisheries Service, \\ Woods Hole, Massachusetts 02543, USA \\ ${ }^{4}$ Present address: College of Marine Science, University of South Florida, St. Petersburg, Florida 33701, USA
}

\begin{abstract}
Most evidence for ontogenetic migration of fishes from mangroves to coral reefs has been based on cross-sectional studies of $<2$ yr duration that have not considered annual variability in recruitment. Taking a longitudinal approach of following cohorts over time, we evaluated evidence for mangrove-derived replenishment of 10 coral reef fishes by drawing on data from 2 concurrent fish monitoring efforts conducted in Biscayne National Park, Florida, USA, over the period 1999 to 2007. Annual indices of abundance were calculated for fish estimated to be age- 0 to $4^{+}$in both habitats, and correlation analyses, with appropriate temporal lags, were performed. Statistically significant $(\mathrm{p}<$ $0.05 ; \mathrm{r}^{2}=0.30$ to 0.71 ) correlations between juvenile abundances in mangrove habitats and adult abundances on the reef tract 1 to 2 yr later emerged for 4 species: Abudefduf saxatilis, Lutjanus apodus, L. griseus, and Sphyraena barracuda. This is one of the few longitudinal studies that uses juvenile abundance indices to test mangrove-reef ontogenetic connectivity. Our results have potential utility for nursery habitat assessment, marine reserve design, and for forecasting species-specific year-class strength on the reef, where most fishing is directed.
\end{abstract}

KEY WORDS: Biscayne Bay · Florida Keys · Longitudinal study · Nursery habitat · Visual survey

\section{INTRODUCTION}

Around the globe, the juvenile stages of many coral reef fishes are often highly abundant within tropical and subtropical mangrove habitats (Austin 1971, Sedberry \& Carter 1993, Nagelkerken et al. 2000a, Serafy et al. 2003, Nakamura \& Sano 2004, Dorenbosch et al. 2005, Unsworth et al. 2008). The submerged prop-roots provide conditions that are favorable for the growth and survival of young reef fishes, which include high levels of appropriate food items (Odum \& Heald 1972, Laegdsgaard \& Johnson 2001, Cocheret de la Morinière et al. 2003) and decreased predation mortality owing to the structurally complex shelter (Robertson \& Duke 1897 , Thayer et al. 1987, Parrish 1989, Laegdsgaard \& Johnson 2001) and reduced encounters with reef-based piscivores (Shulman 1985, Parrish 1989, Mumby et al. 2004).
However, the extent to which inshore marine habitats (including mangroves) are occupied by immature fishes has been questioned as a suitable criterion for assessing the ecological importance of these juvenile habitats as nurseries. Beck et al. (2001) contended that habitats exploited by juvenile fishes should only be designated as functional nurseries if it can be established that their residents contribute towards replenishment of individuals in adult habitats. Mangroves that lie adjacent to coral reefs may be important to the reef ichthyofauna if they undergo ontogenetic migrations from putative mangrove nurseries to replenish nearby populations of reefdwelling adults (Nagelkerken et al. 2000b, Ley \& McIvor 2002, Mumby et al. 2004, Nakamura et al. 2008, Unsworth et al. 2008). However, if such migrations do not occur, the mangroves may represent a sink rather than a source of potential recruits. 
There is mounting evidence of inter-habitat connectivity between mangroves and reefs from recent studies comparing fishes from these 2 habitats in terms of length frequencies (e.g. Ley et al. 1999, Nagelkerken et al. 2000a, Serafy et al. 2003, Mumby et al. 2004), densities (Halpern 2004), stable isotopes (Nakamura et al. 2008), otolith microchemistry (Chittaro et al. 2004), and implanted tags (Verweij et al. 2007, Luo et al. 2009). However, questions surrounding the designation of mangroves as functional nurseries and the role ontogenetic habitat shifts of reef fishes play in interhabitat connectivity and subsequent population replenishment persist for several reasons. First, most previous work has focused only on juvenile or adult habitats and life-history stages employing methodologies that precluded comparisons between the two (Nagelkerken 2007). Second, the historical emphasis

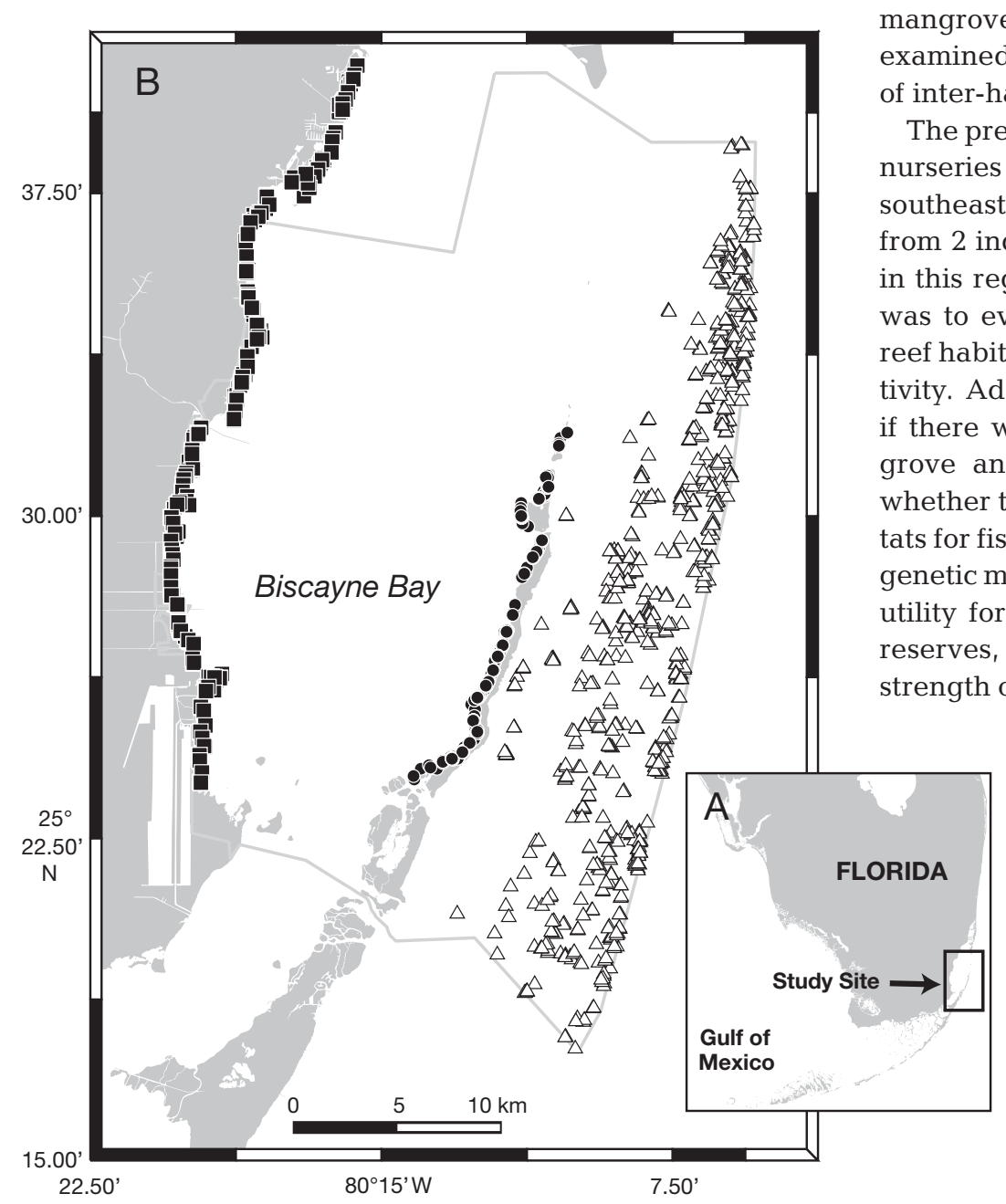

Fig. 1. (A) Study area, off the southeastern tip of Florida, USA. (B) Visual survey sites sampled within the study area; $\mathbf{\square}, \boldsymbol{\bullet}=$ mangrove shoreline transects located off the mainland (ML) and leeward keys (LK), respectively; $\Delta=$ coral reef quadrats $(\mathrm{RF})$ sampled within the bounds (gray line) of Biscayne National Park, Florida, USA has been on patterns too small to yield results of abundance, diversity, and size (age) structure over ecologically meaningful spatial and temporal scales (Pittman \& McAlpine 2003).

Although evidence of connectivity between populations of mangrove and reef fishes is accumulating, it is based mostly on short-term studies $<2$ yr in duration (Nagelkerken 2007). This limits our understanding of the influence of annual variability in juveniles within putative mangrove nurseries on the dynamics of nearby adult reef fish populations (Ogden \& Gladfelter 1983, Roberts 1996, Blaber 2000). Specifically, the literature reflects lack of commitment and/or resources for sustaining long-term monitoring of adjacent mangrove and coral reef habitats. Longer time series allow each annual cohort to be followed for several years across different habitats (i.e. longitudinal observations). Lagged correlations between abundances of juveniles in mangroves and adults on adjacent reefs can then be examined to determine whether they provide evidence inter-habitat connectivity.

The present study evaluated mangroves as functional nurseries for reef fishes in Biscayne National Park in southeastern Florida, USA (Fig. 1). Data were analyzed from 2 independent efforts that have monitored fishes in this region for over a decade. The aim of this work was to evaluate connectivity between mangrove and eef habitat by testing the null hypothesis of no connecwhether the reefs require intermediate (nursery) habitats for fish replenishment. Significant findings of ontogenetic migrations from mangroves to reefs would have utility for defining nursery habitat, designing marine reserves, and forecasting species-specific year-class rength on the reef where most fishing is directed.

\section{MATERIALS AND METHODS}

Study site. This study examined fishes of southeastern Florida (USA) that occupy habitats within Biscayne National Park (BNP, Fig. 1), one of the largest marine parks (ca. $700 \mathrm{~km}^{2}$ ) in the US National Park system. BNP encompasses much of Biscayne Bay and its shallow inshore habitats, but also extends ca. $10 \mathrm{~km}$ offshore to include the northernmost coral colonies of the Florida Keys reef tract (Fig. 1), which is the third-longest chain of coral reefs in the world. The subtropical coastal waters of southeastern Florida provide a diversity of habitats that are utilized to varying de- 
grees by freshwater, marine, and euryhaline fishes, including species believed to make shifts among habitats with ontogeny (e.g. Thayer et al. 1987, Ley \& McIvor 2002, Serafy et al. 2003, Adams et al. 2006). Southeastern Florida's bays have long been thought to provide nursery habitats for several fish species that use inshore waters as juveniles before emigrating at maturity to offshore reefs where spawning occurs and adult stages are more commonly found (e.g. Croker 1962, de Sylva 1963, Starck 1970, Rutherford et al. 1989). Many of these species form a substantial component of the commercial and sport fisheries in the region, which contribute significantly to the State's economy (Bohnsack \& Ault 1996, Browder et al. 2007). With the exception of a few protected areas, fishing restrictions are the same as for the state of Florida.

Data sources. Data were examined from 2 on-going, fishery-independent surveys of fish communities occupying (1) mangrove shorelines of Biscayne Bay (Serafy et al. 2003) and (2) coral reefs off the Florida Keys (Bohnsack et al. 1999). The mangrove data were collected via visual surveys conducted along $2 \times 30 \mathrm{~m}$ belt transects run parallel to the shoreline (Rooker \& Dennis 1991, Serafy et al. 2003). On the reef, circular $15 \mathrm{~m}$ diameter quadrats were surveyed using a stationary visual method (Bohnsack \& Bannerot 1986). Both studies recorded abundance and size (minimum, mean, and maximum total length) of each taxon observed within each sampling unit, and followed similar random stratified experimental designs (Ault et al. 1999, Serafy et al. 2003). For the present analysis, updated subsets of these data were extracted for the period 1999 to 2007 from all mangrove transects that fell within mainland (ML) or leeward key (LK) sampling strata and all reef quadrats (RF) within the boundaries of Biscayne National Park (Table 1). The study area and the location of all visual survey sites and associated sampling strata are depicted in Fig. 1.

Table 1. Number of visual surveys by year used in the present analysis. Mangrove transects in Biscayne Bay are partitioned according to habitat stratum: mainland ( $M L, n=657$ ), leeward key $(\mathrm{LK}, \mathrm{n}=324)$; Biscayne National Park reef quadrats $(\mathrm{RF}, \mathrm{n}=931)$

\begin{tabular}{|rrrr|}
\hline Year & ML & LK & RF \\
\hline 1999 & 32 & 27 & 37 \\
2000 & 27 & 29 & 62 \\
2001 & 28 & 29 & 76 \\
2002 & 41 & 40 & 147 \\
2003 & 50 & 39 & 115 \\
2004 & 56 & 40 & 155 \\
2005 & 110 & 40 & 132 \\
2006 & 141 & 39 & 98 \\
2007 & 172 & 41 & 109 \\
\hline
\end{tabular}

Overall, 99 and 365 fish species were present within the subsets of the mangrove (Serafy et al. 2003) and reef (Bohnsack et al. 1999) data sets, respectively, with a total of 68 taxa occurring within both habitats. Of these, 10 target species from 7 families were identified as having the potential to exhibit ontogenetic shifts between the 2 habitats. These include commercially and recreationally valuable species (i.e. Haemulon flavolineatum, H. parra, H. sciurus, Lutjanus apodus, L. griseus, and Sphyraena barracuda), other numerically abundant taxa (i.e. Abudefduf saxatilis, Gerres cinereus, and Lagodon rhomboides), and a large herbivore currently red-listed as a vulnerable species (IUCN 2008): Scarus guacamaia. Target species designation was based on presence within both mangrove and reef data sets each year at levels of at least $1 \%$ of the total number of sites surveyed.

Abundances by age class. For each of the target species, length-frequencies of each sample were estimated using a method based on the observed fish size data (Ault et al. 1998, Meester et al. 1999, Serafy et al. 2003, 2007, Faunce \& Serafy 2007). This technique employs a smoothing function that maps these data as parameters of a frequency distribution having a mode and lower/upper bounds defined by the observed mean size and minimum/maximum sizes, respectively. Since fish size data were recorded as total length (TL, $\mathrm{cm}$ ) in the mangrove surveys, the reef data were converted from fork length to TL using formulae provided in FishBase (Froese \& Pauly 2008) for unit consistency. For each species, the length-frequencies were used to partition the abundance data of each sample into one of 5 age classes (i.e. age- 0 to $4^{+}$) using von Bertalanffy growth functions. When $t_{0}$ was unavailable, it was estimated using the following (after Pauly 1980):

$$
\begin{gathered}
\log _{10}\left(-t_{0}\right)=-0.3922-0.2752 \times \\
\log _{10}\left(L_{\mathrm{a}}\right)-1.038 \times \log _{10}(K)
\end{gathered}
$$

where $t_{0}$ is the theoretical age when length is zero, $L_{\mathrm{a}}$ is the theoretical asympotic total length ( $\mathrm{mm})$, and $K$ is the annual growth coefficient. When $L_{\mathrm{a}}$ was unavailable, it was estimated using the following (after Froese \& Binohlan 2000):

$$
\log _{10}\left(L_{\mathrm{a}}\right)=0.044+0.9841 \times \log _{10}\left(L_{\max }\right)
$$

where $L_{\max }$ is the maximum reported total fish length $(\mathrm{mm})$. For each of the target species, details of the sources of parameters of the growth functions used are given in Table 2, size ranges defining age classes are provided in Table 3, and observed fish sizes are tabulated by habitat in Table 4. Plots of relative abundances, partitioned according to age-class, were constructed for each target species to assess the relative contribution of each age-class to the populations occurring within the mangrove shoreline and coral reef habitats. 
Table 2. von Bertalanffy growth function parameters for the 10 target species. $L_{\mathrm{a}}=$ theoretical asymptotic total length $(\mathrm{mm}), K=$ annual growth coefficient, $t_{0}=$ theoretical age when length $=0$. Source: ${ }^{\mathrm{a}}$ mean of parameters available for Stegastes planifrons and S. partitus (Schwamborn \& Ferreira

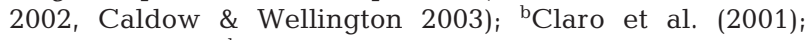
${ }^{\mathrm{c}}$ Dennis (1988); ${ }^{\mathrm{d} C l a r o}$ \& García-Arteaga (2001); ${ }^{\mathrm{e}}$ Martinez-

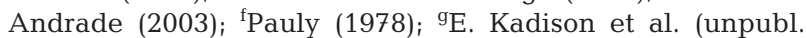
data). Parameters in bold are estimated (see methods)

\begin{tabular}{|lrrr|}
\hline Taxon & $L_{\mathrm{a}}$ & $K$ & \multicolumn{1}{c|}{$t_{0}$} \\
\hline Abudefduf saxatilis $^{\mathrm{a}}$ & $\mathbf{2 4 1 . 1}$ & 0.200 & -2.300 \\
Gerres cinereus $^{\mathrm{b}}$ & 340.8 & 0.650 & 0.000 \\
Haemulon flavolineatum $^{\mathrm{c}}$ & 392.5 & 0.240 & -0.670 \\
H. parra $^{\mathrm{d}}$ & 420.6 & 0.240 & -0.270 \\
H. sciurus $^{\mathrm{b}}$ & 351.6 & 0.220 & -0.640 \\
Lagodon rhomboides $^{\mathrm{b}}$ & 212.7 & 0.590 & -0.270 \\
Lutjanus apodus $^{\mathrm{e}}$ & 547.0 & 0.223 & -0.497 \\
L. griseus $^{\mathrm{e}}$ & 670.0 & 0.168 & -0.695 \\
Scarus guacamaia $^{\mathrm{f}}$ & $\mathbf{1 2 3 0 . 6}$ & 0.293 & $\mathbf{- 0 . 3 8 5}$ \\
Sphyraena barracuda $^{\mathrm{g}}$ & 1498.7 & 0.216 & 1.690 \\
\hline
\end{tabular}

Table 3. Predicted lengths (TL, mm) for the 10 target species based on von Bertalanffy growth functions

\begin{tabular}{|lcccc|}
\hline Taxon & Age 1 & Age 2 & Age 3 & Age $4^{+}$ \\
\hline Abudefduf saxatilis & 116 & 139 & 158 & 173 \\
Gerres cinereus & 163 & 248 & 292 & 315 \\
Haemulon flavolineatum & 130 & 186 & 230 & 265 \\
H. parra & 111 & 177 & 229 & 270 \\
H. sciurus & 106 & 155 & 194 & 225 \\
Lagodon rhomboides & 112 & 157 & 182 & 196 \\
Lutjanus apodus & 155 & 234 & 296 & 346 \\
L. griseus & 166 & 244 & 310 & 366 \\
Scarus guacamaia & 410 & 619 & 774 & 890 \\
Sphyraena barracuda & 660 & 823 & 955 & 1060 \\
\hline
\end{tabular}

Table 4. Size range, reported as minimum-maximum (mean) total length (TL, $\mathrm{mm}$ ) for each of the 10 target taxa observed during visual surveys of mangrove transects in Biscayne Bay $(\mathrm{n}=981)$ and reef quadrants in Biscayne National Park $(\mathrm{n}=931)$, Florida, USA during 1999-2007

\begin{tabular}{|lrrrrrr|}
\hline \multirow{2}{*}{ Species } & \multicolumn{4}{c}{ Mangrove } & \multicolumn{3}{c|}{$\begin{array}{c}\text { Reef } \\
\end{array}$} & Min. & Max. & Mean & Min. & Max. & Mean \\
\hline Abudefduf saxatilis & 12.7 & 203.2 & 60.4 & 22.6 & 226.4 & 110.6 \\
Gerres cinereus & 25.4 & 406.4 & 127.7 & 121.7 & 304.3 & 209.8 \\
Haemulon flavolineatum & 25.4 & 152.4 & 86.3 & 32.8 & 338.0 & 139.6 \\
H. parra & 25.0 & 330.2 & 97.6 & 43.4 & 325.2 & 173.6 \\
H. sciurus & 25.4 & 406.4 & 126.0 & 31.0 & 361.9 & 168.2 \\
Lagodon rhomboides & 25.4 & 254.0 & 90.6 & 132.2 & 231.4 & 159.8 \\
Lutjanus apodus & 25.4 & 355.6 & 120.1 & 61.0 & 529.0 & 221.6 \\
L. griseus & 12.7 & 457.2 & 176.8 & 62.9 & 472.0 & 216.7 \\
Scarus guacamaia & 63.5 & 609.6 & 201.2 & 140.0 & 700.0 & 372.6 \\
Sphyraena barracuda & 38.1 & 990.6 & 240.6 & 306.6 & 2148.7 & 837.7 \\
\hline
\end{tabular}

Habitat connectivity. The abundances of fishes for each combination of age-class/sampling year were used to calculate mean annual abundances separately for data obtained within the 3 habitat strata considered (i.e. ML, LK, and RF). Mangrove data were subsetted by ML and LK because previous work has consistently revealed significant differences in reef fish abundance between these 2 mangrove strata (Serafy et al. 2003, Faunce \& Serafy 2007, Faunce \& Serafy 2008). Global mean fish abundances, calculated by pooling abundances across years for each combination of age-class/ habitat strata, were subtracted from corresponding annual mean fish abundances. This produced a residual abundance metric (Winer 1971) indicating years that were above the central tendency of each annual series when positive and below when negative (i.e. relatively high/low abundances). The concordance between abundance indices derived for juvenile mangrove fishes (ML, LK) with those for subadult and adult fishes on adjacent reefs (RF) were then examined. This allowed for species-specific assessments of evidence of connectivity (or lack thereof) among mangrove and reef populations that were consistent with ontogenetic migrations between habitats (i.e, mangrove-to-reef). Hereafter, 'juvenile', 'subadult', and 'adult', respectively, refer to fish that are less than age-1, immature but at least age-1, and sexually mature.

A square-root transformation was applied to the observed abundance data before calculating indices to minimize the impact of outliers and linearize the relationships that may occur between mangrove and reef indices (McCune et al. 2002). Linear correlations were calculated separately for the indices of both age- 0 and age- 1 mangrove fish against indices for age- 1 to age $-4^{+}$ reef fish. A temporal lag of 1 to $4 \mathrm{yr}$ was incorporated into these comparisons to allow time for ontogenetic migrations of fishes between habitats to occur, by offsetting the reef indices the appropriate number of years. Note that comparisons of mangrove versus reef indices were made separately for indices based on mangrove type (ML or LK) and mangrove age-class (age-0 and age-1). That is, indices based on age-0 mangrove fish were compared to indices based on age- 1 to age $-4^{+}$reef fish, while age- 1 mangrove fish were compared to indices based on age- 2 to age $-4^{+}$reef fish. The impact of reef-based juveniles, which do not undergo ontogenetic habitat shifts, on subsequent adult abundance was assessed by examining correlations among lagged abundance indices as before, but this time using age- 0 and age- 1 juveniles from the reef 
instead of the mangroves. Finally, the congruence of juvenile population flux in the mangroves with that on the reef during the same year was examined by comparing abundance indices of age- 0 and age- 1 juveniles among both habitats with no temporal lag applied.

Statistical significance of the linear correlations between indices were evaluated using distribution-free randomization tests ( $\mathrm{n}=1000$ iterations), eliminating reliance on the underlying assumptions of any one distributional model (Anderson 2001, McArdle \& Anderson 2001, Petraitis et al. 2001). Adjustments for multiple comparisons were not applied to the significance tests as these were deemed too conservative given the limited number of comparisons made in this study. Plots of linear regressions for age- 0 and age- 1 juvenile fishes were made for those pairs of mangrove-reef or reef-reef indices yielding significant positive correlations at an $\alpha$ level of 0.05 . All data manipulations, statistical analyses, and plotting were performed using the Fathom Toolbox for Matlab (Jones 2002).

\section{RESULTS}

\section{Spatial segregation by age class}

Inspection of the species-specific plots of percent relative abundance by age-class provided in Fig. 2 suggests 4 general patterns of habitat usage. First, most species display the same pattern of differential habitat utilization with developmental stage, with marked dominance of early stage fish in the mangroves yielding to increased prominence of subsequent age classes on the reef. Second, while the above trend is evident to some degree in most taxa, age-0 fish of 2 species, $A b u-$ defduf saxatilis and Scarus guacamaia, figure prominently within populations of both mangrove and reef habitats. Third, these 2 species, along with Haemulon flavolineatum and Sphyraena barracuda, inhabit the mangrove shorelines of Biscayne Bay almost exclusively as age-0 fish. Fourth, relative abundance plots suggest $H$. flavolineatum and Lutjanus apodus occupy mangrove habitats during earlier developmental stages and for shorter portions of their lifespan than their generic counterparts, H. sciurus and L. griseus.

\section{Evidence of inter-habitat connectivity}

Species-specific pair-wise comparisons between annual abundance indices of mangrove and reef fishes that yielded significant, positive correlations are tabulated in Appendix 1, with corresponding linear regression and time series plots provided in Figs. $3 \& 4$, respectively. For the 4 species with significant correla- tions (Abudefduf saxatilis, Lutjanus apodus, L. griseus, and Sphyraena barracuda) (Appendix 1, Fig. 3), the significant results provide evidence for rejecting the null hypothesis of no connectivity between habitats for the corresponding age-classes and mangrove strata. Significant results also suggest that juvenile abundance in mangroves is predictive of year class strength on the reef $\geq 1$ yr later. For the remaining 6 species with sufficient observations for analysis, non-significant correlations mean that the null hypothesis (no habitat connectivity) could not be rejected.

Examination of commonalities among the correlations with significant results reveals the following: First, all significant results were based on juvenile mangrove data from the LK strata, except for age-0 Lutjanus apodus, which were from the ML strata (Fig. 3C). Second, most of the significant models were based on age-1 juveniles (Abudefduf saxatilis, L. apodus, L. griseus, Sphyraena barracuda; Fig. 3B,D-F), with the remainder on age-0 (A. saxatilis, L. apodus; Fig. 3A,C). Third, half of the models incorporated a temporal lag between mangrove and reef cohorts of 1 yr (A. saxatilis, L. apodus, L. griseus; Fig. 3A,D-E), with the remainder involving a 2-yr lag (A. saxatilis, $L$. apodus, S. barracuda; Fig. 3B-C,F).

\section{Reef-based juveniles}

Correlations among abundance indices for reefbased juveniles - those not involved with ontogenetic habitat shifts - yielded a single significant relationship associated with age-0 Haemulon parra and a temporal lag of 1 yr (Appendix 1, Fig. 5). We note that this was not a species with a significant result for interhabitat correlation. Thus, for 9 out of 10 species, there is no evidence in the present study that populations on the reef are replenished without involving intermediary nursery habitat. Finally, comparisons between age0 and age- 1 mangrove fishes with their counterparts of the same age on the reef during the same year revealed no significant relationships in terms of annual abundance of juveniles (Appendix 1). Thus, there is no evidence of similar year effects between the 2 habitat types.

\section{DISCUSSION}

Longitudinal analysis of 2 long-term data sets provided evidence of inter-habitat connectivity for 4 out of 10 species (Abudefduf saxatilis, Lutjanus apodus, L. griseus, and Sphyraena barracuda). The chance that these results are spurious is diminished by the fact that there were no significant year effects between habi- 

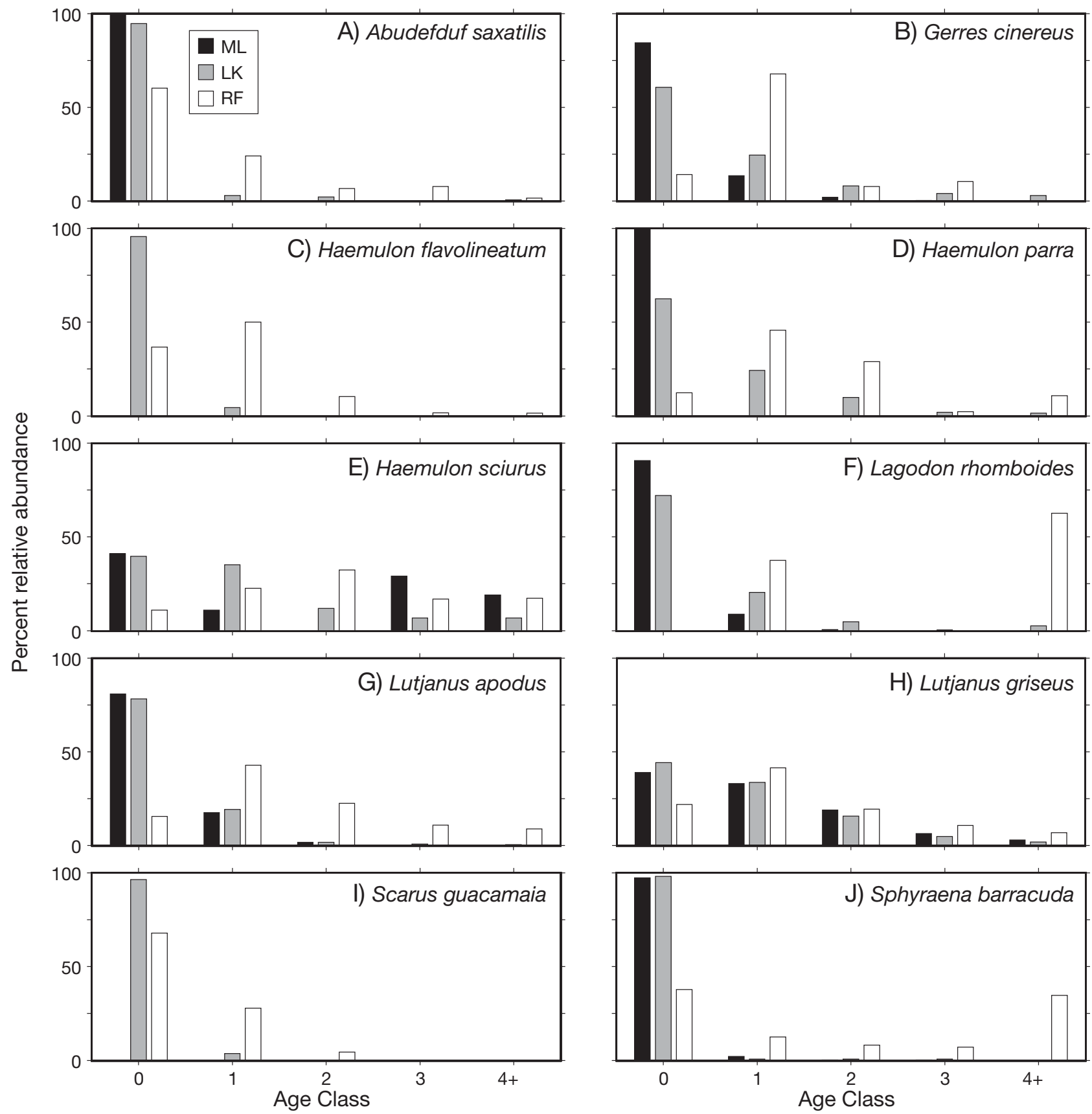

Fig. 2. Mean percent relative abundance (by age-class) for 10 species of fishes encountered in visual surveys of mainland (ML, $\mathrm{n}=$ $657)$ and leeward key $(L K, n=324)$ mangrove shoreline transects in Biscayne Bay, and coral reef quadrats (RF, $n=931)$ in Biscayne National Park, Florida, USA. Corresponding mean abundances (no. of fish per $60 \mathrm{~m}^{2}$ ) pooled across age classes for each habitat stratum (i.e. ML, LK, RF, respectively) are as follows: (A) $0.035,0.595,0.692 ;$ (B) $0.918,1.143,0.024 ;$ (C) $0,0.261,1.268$; (D) $0.033,1.109,0.051$; (E) 0.014, 3.562, 1.196; (F) 0.254, 0.921, 0.006; (G) 0.131, 0.855, 0.372; (H) 0.741, 5.788, 0.832; (I) 0, 0.629, 0.075; (J) $0.551,0.926,0.082$. See Table 3 for fish lengths corresponding to the plotted age classes

tats, and that patterns for only 1 out of 10 species (Haemulon parra) suggested that intermediate habitat was not a step in reef population replenishment. Although 6 out of 10 species failed to reject the null hypothesis of no inter-habitat connectivity, pooling the data across years revealed a clear trend in percent relative abundance. Specifically, the earliest developmental stages occurred most prominently within the mangrove habitats of BNP, with later stages comprising the dominant components of offshore reef fish populations. This was true for 8 of the target species examined: Gerres cinereus, Haemulon flavolineatum, H. parra, H. sci- 

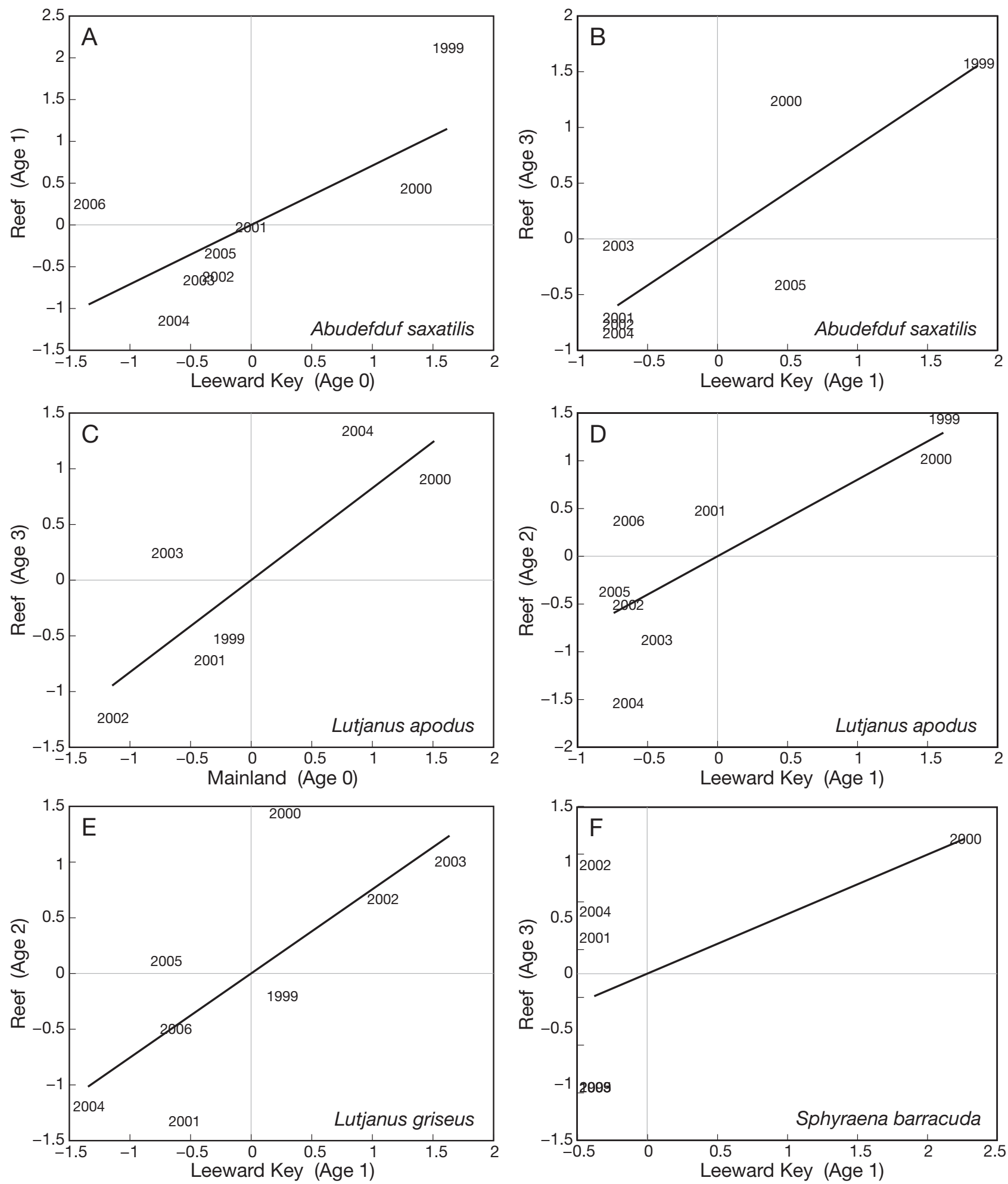

Fig. 3. Abudefduf saxatilis, Lutjanus spp., and Sphyraena barracuda. Regression plots of significant correlations (r, where $\mathrm{p}<$ 0.05) between annual mangrove and reef abundance-based indices for species of fishes encountered in visual surveys of the mangrove shorelines of Biscayne Bay and the coral reefs of Biscayne National Park, Florida, USA. Data points are labeled with sampling year associated with the abscissa (mangrove fishes); sampling years of the ordinate (reef fishes) equal those of the abscissa + temporal lag (yr) associated with each plot as follows: (A) A. saxatilis: $\mathrm{r}^{2}=0.50$, lag $=1$; (B) A. saxatilis: $\mathrm{r}^{2}=0.71$, lag $=2$; (C) L. apodus: $\mathrm{r}^{2}=0.69$, lag = 2; (D) L. apodus: $\mathrm{r}^{2}=0.64$, lag $=1 ;(\mathrm{E})$ L. griseus: $\mathrm{r}^{2}=0.58$, lag $=1 ;(\mathrm{F})$ S. barracuda: $\mathrm{r}^{2}=0.30$, lag $=1$ 

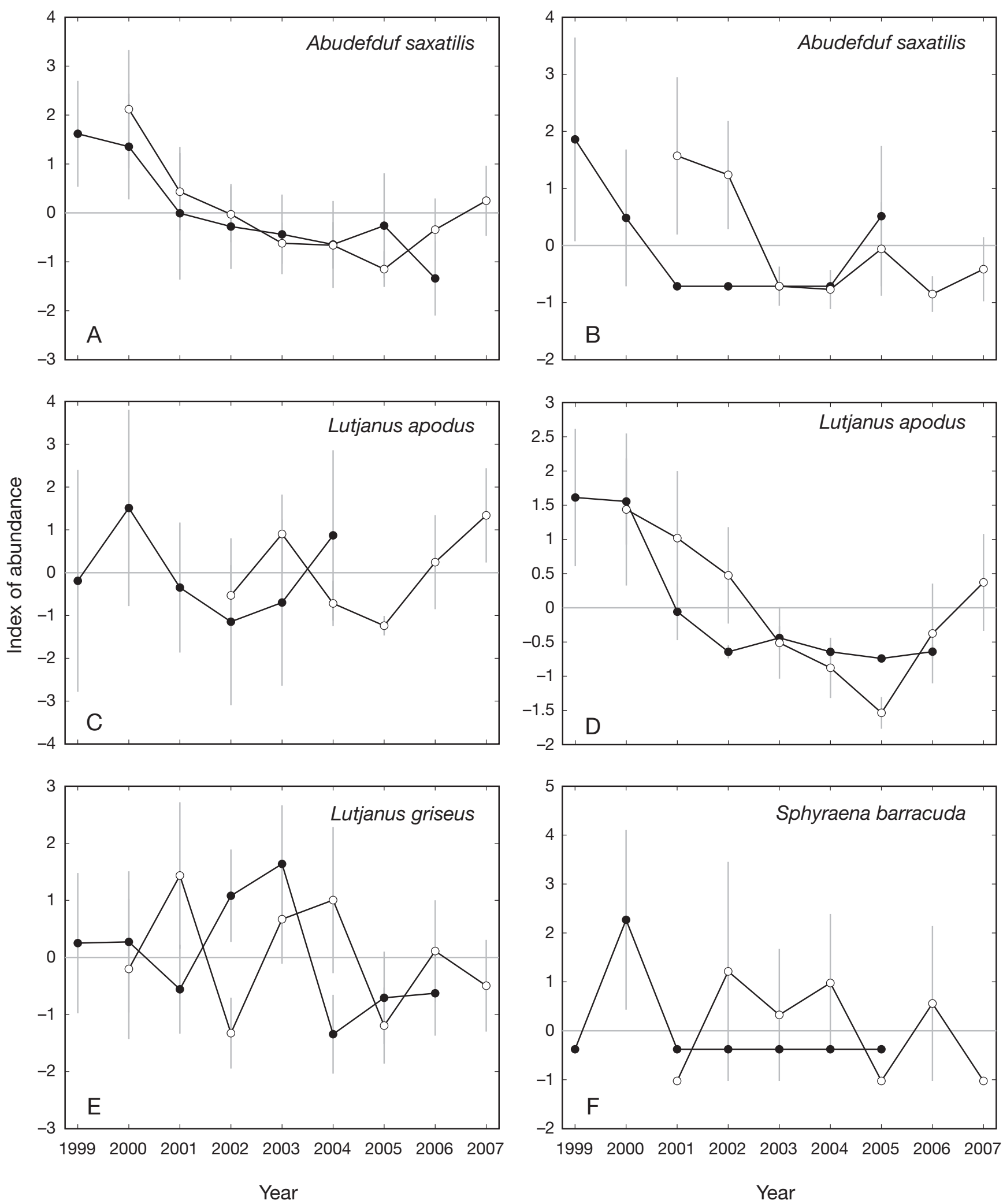

Fig. 4. Abudefduf saxatilis, Lutjanus spp., and Sphyraena barracuda. Time series of pairs of mangrove $(\bullet)$ and reef $(0)$ annual abundance indices $( \pm \mathrm{SE})$ that yielded significant correlations $(\mathrm{r}$, where $\mathrm{p}<0.05)$; (A) A. saxatilis: age-0 leeward key, LK, and age-1 reef, $\mathrm{RF}_{;}(\mathrm{B})$ A. saxatilis: age-1 LK and age-3 RF; (C) L. apodus: age-0 mainland and age-3 RF; (D) L. apodus: age-1 LK and age-2 RF; (E) L. griseus: age-1 LK and age-2 RF; (F) $S$. barracuda: age-1 LK and age-3 RF 


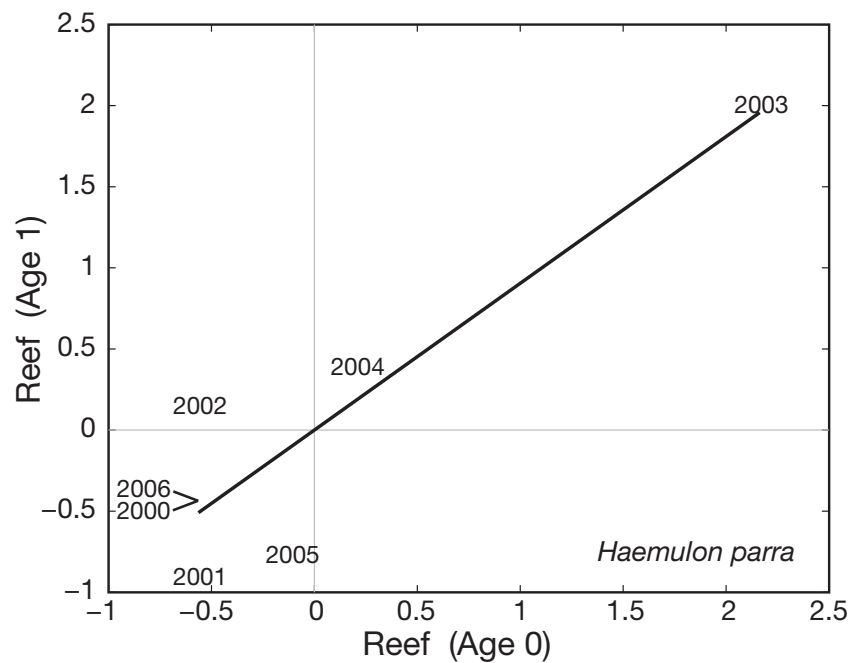

Fig. 5. Haemulon parra. Significant, positive correlation $\left(\mathrm{r}^{2}=\right.$ $0.81, \mathrm{p}<0.05$ ) between annual abundance indices based on reef-dwelling $H$. parra encountered in visual surveys of the coral reefs of Biscayne National Park, Florida, USA. Data points are labeled with the sampling year associated with the abscissa (age-0 reef fish); sampling years of the ordinate (age-1 reef fish) equal those of the abscissa + temporal lag $(=1 \mathrm{yr})$

urus, Lagodon rhomboides, Lutjanus apodus, L. griseus, and Sphyraena barracuda. These patterns of spatial segregation of life history stages provide first order evidence that the offshore reefs of BNP are connected to the mangrove-lined shores of the bay by ontogenetic migrations of fishes between juvenile and adult habitats. Similar results were reported for fishes in the Netherlands Antilles, where the importance of mangrove juvenile habitat and evidence of ontogenetic shifts in habitat was inferred from the distribution and abundance of several reef fishes (Nagelkerken et al. 2000a,b, Nagelkerken \& van der Velde 2002). With the exception of L. rhomboides, these included 7 of the 8 species for which ontogenetic movement was found in the present study.

Previous results from work in BNP comparing size distributions of fishes in mangroves versus the adjacent reef suggested that ontogenetic shifts occurred in only 2 species: Lutjanus apodus and Sphyraena barracuda (Serafy et al. 2003). Unlike the present study, evidence of ontogenetic shifts was not detected in Gerres cinereus, Haemulon parra, H. sciurus, or L. griseus. However, these comparisons were made using data sets that were much smaller than those in the present study - their reef data were limited to 38 quadrats sampled over a span of $5 \mathrm{yr}$ - and were based on different experimental sampling designs.

In the present study, an annual index of relative reef fish abundance was developed for 10 species of fishes that occur in the waters of BNP. Significant correlations validated the indices as predictive models for forecast- ing relative adult abundances for 4 species (Abudefduf saxatilis, Lutjanus apodus, L. griseus, and Sphyraena barracuda). This corroborates the notion that the mangroves in BNP are connected to adjacent reefs through ontogenetic migration by juvenile reef fishes, and that the mangroves serve as functional nurseries (sensu Beck et al. 2001) for those fishes. It is likely, though, that the significant correlation for $S$. barracuda was entirely driven by the high 2000 year class. Those species for which a significant correlation was found apparently exploit mangroves for nursery habitat, as is supported by evidence from the Caribbean for several species of reef fishes, including L. apodus, L. griseus, and $S$. barracuda (Nagelkerken et al. 2002).

Of the target species, 4 (i.e. Abudefduf saxatilis, Lutjanus apodus, L. griseus, and Sphyraena barracuda) were present in relatively high abundances as juveniles within the bay during the year 2000 and as subadults and adults on adjacent reefs the following year (or 2). These are the same species that yielded significant correlations among lagged mangrove and reef abundance indices. Thus, an ecosystem-wide perturbation in year-class strength in populations of 4 species of fishes inhabiting mangrove shorelines of BNP during 2000 was observed to propagate along cohorts inhabiting adjacent reefs 1 to 2 yr later. The nature and extent of this perturbation is unknown.

For 6 of the 10 target species, no significant relationships between annual abundance indices were detected between mangrove and reef populations. This lack of correspondence may be attributed to the underlying biology and ecology of each species in question. For example, mangroves may not serve as nurseries (sensu Beck et al. 2001) for these fishes. Haemulon flavolineatum can utilize alternative juvenile habitats when available (Nagelkerken et al. 2002), do not occupy mangroves as long as other haemulids, and can also directly settle on the reef and use that as a juvenile habitat (Shulman \& Ogden 1987, Nagelkerken et al. 2000b). Gerres cinereus have been observed to use mangroves as their primary juvenile habitat, but they are also commonly found in high densities as juveniles on mud flats, and only a portion of the adult population make ontogenetic shifts to adjacent coral reefs (Nagelkerken et al. 2000a, Nagelkerken \& van der Velde 2002); thus, their dependence on mangroves is considered to be low (Nagelkerken et al. 2001).

The lack of correlation among mangrove and reef annual abundance indices in other species may have simply resulted from a lack of movement on the part of the fish or movement that exceeded the spatial domain of the study area (i.e. for these species, BNP is not a closed system). The latter consideration may apply for Scarus guacamaia, which are known to have exceedingly large home-ranges on coral reefs as adults 
(Mumby 2006). Other reasons for the lack of correlations between mangrove and reef indices include differential fishing pressure applied to large size-classes of fishes on the reef (Serafy et al. 2003). For the exploited species (e.g. Lutjanus spp., Haemulon spp., and Sphyraena barracuda), fishing pressure may effectively reduce cohort variability to levels beyond our detection.

Of the target species, 2 (Abudefduf saxatilis and Lutjanus apodus) showed significant correlations among mangrove and reef abundance indices with a temporal lag of $2 \mathrm{yr}$, rather than 1 . This could result from a lag in the time it takes to complete the migration of a cohort to the reef or from utilization of intermediate habitats between the mangroves and the reefs. It is unlikely that an entire cohort would complete migration from the mangroves to the reef in a single year; nevertheless, observation of that cohort at lags of $2 \mathrm{yr}$ provides evidence that the migration occurred.

It should be noted that our method of assigning ages based upon lengths has the tendency to smooth through annual cohorts. This bias operates when the greater total numbers of fish in high recruitment years, coupled with the natural variability in size at age, place more fish into either smaller or larger size bins that get mis-assigned to other ages (Lassen 1988). Furthermore, density-dependent variability in growth rate would also tend to reduce the contrast between high and low recruitments. Collectively, these biases would weaken correlations between lagged abundances in mangrove and reef habitats and, therefore, decrease the likelihood of accepting the hypotheses of connectivity.

A notable exception to the general pattern of spatial segregation of life history stages described above was observed for Abudefduf saxatilis, where high relative abundances of juveniles (age-0) occurred in both mangrove and reef habitats. This suggests early juveniles of this species recruit to both mangrove and reef habitats, with individuals in the former either migrating at later developmental stages to the reef or succumbing to predation and other sources of mortality in the mangroves. Indeed, examination of the size ranges of these damselfish shows considerable overlap in utilization of mangroves and reefs as juvenile habitats. A similar pattern was reported for Caribbean populations of $A$. saxatilis (Nagelkerken et al. 2000a,b, Nagelkerken \& van der Velde 2002).

Juveniles of most coral reef damselfishes generally avoid occupying non-reefal habitats because of the high risks involved during subsequent migration to the adult habitat (Shulman 1985, Adams \& Ebersole 2002). Juvenile use of mangroves may also be less important for small species of reef fishes like damselfish, since they can often gain sufficient shelter within coral branches on offshore reefs (Hixon 1991, Nagelkerken $\&$ van der Velde 2002). Species with larger juveniles (e.g. haemulids and lutjanids) require a more structurally complex shelter such as that afforded by the submerged prop roots of mangroves (Laegdsgaard \& Johnson 2001). However, several lines of evidence from the present study suggest that mangrove shorelines in BNP may be more important than offshore reefs as a juvenile habitat for Abudefduf saxatilis. First, significant results were obtained for 2 developmental stages (age0 and age-1) of this species linking annual abundance indices of mangrove-based juveniles with lagged indices of reef-based damselfishes. Second, while juveniles displayed high relative abundances in mangroves and on reefs, comparisons of fluctuations in annual abundance indices during the same year (i.e. year effects) indicated no evidence of synchronous pulses between these 2 habitats. Third, unlike mangrove-based juveniles, fluctuations in abundances of reef-based juvenile $A$. saxatilis were not predictive of subsequent year-class strength on the reef. This combination of evidence presents a convincing argument that (1) this species undergoes ontogenetic habitat shifts, and (2) mangrove shorelines provide an important nursery habitat that substantially contributes to the replenishment of the adult population on adjacent reefs.

While the majority of target species in the present study displayed limited overlap in developmental stages across habitats, juvenile (age-0) Scarus guacamaia occurred as dominant components of both inshore mangrove and offshore reef populations. As with Abudefduf saxatilis, one might conclude this suggests early juveniles of this parrotfish exploit either mangroves or reefs for juvenile habitats. However, previous studies have not only shown juvenile $S$. guacamaia require mangroves as their exclusive nursery habitat (Randall 1967, Nagelkerken et al. 2000a, Nagelkerken \& van der Velde 2002), they also have established these fish occur only on reefs that are in close proximity to such areas (Mumby et al. 2004, Dorenbosch et al. 2006, 2007). Therefore, it can be argued that the 'age-0' parrotfishes observed on the reefs of BNP did not initially settle there, but rather were more likely age- 0.5 individuals that shifted habitats after previously residing in the adjacent mangroves at developmental stages (sizes) similar to those reported in the mangroves of the Netherlands Antilles (Nagelkerken et al. 2000a, Dorenbosch et al. 2006). None of the lagged correlations between mangrove and reef abundance indices for S. guacamaia were significant. However, the lack of available high resolution age and growth information limits the precision of length-based age assignments of this species (Table 2), which may obscure the detection of habitat linkages that may exist for these parrotfishes, especially given the obligatory dependence on mangroves for putative nursery habitat observed in previous studies. 
This study suggests that mangrove shoreline habitats serve as nurseries for reef fishes within BNP. The management implication of this finding calls for targeting these areas for increased protection during a time when Park management is formulating its very first fishery management plan. The relationships derived here also hold great promise for providing managers with (1) a means to predict reef fish relative abundance 1 to 2 yr into the future, and (2) validated, fisheryindependent recruitment indices which can be essential elements of stock assessments. To date, lengthbased reef fish assessments using visual survey data for the Florida reef tract (e.g. Ault et al. 1998) have not considered the influence of recruitment variability on average length. Furthermore, few assessments of reef fishes incorporate recruitment indices, which the present study makes available. As this marine park is bordered by Miami-Dade county, the sixth largest urbanized area in the USA, burgeoning urban development and human population growth threaten the region with continued overfishing (Berkeley \& Campos 1984, Berkeley et al. 1985, Ault et al. 1998), sustained loss of essential fish habitat (Dustan \& Hallas 1987, Porter \& Meier 1992, Browder \& Ogden 1999), and persistent alteration of the historically natural freshwater flow regime (Tabb et al. 1974, de Sylva 1976, Serafy et al. 1997). Thus, the critical habitat linkages demonstrated by the present study are of particular relevance for incorporating an ecosystem-based approach towards management of this and similar mangrove-reef systems, especially those that rim the Caribbean Basin. In fact, Mumby (2006) has developed algorithms for the design of marine reserves, which explicitly incorporate mangroves as nursery habitats for economically important species of reef fishes.

From the results of the present study, 4 main conclusions can be drawn. First, there is spatial segregation of life history stages in a number of species of reef fishes that reside in BNP, with juveniles occupying mangroves in the bay and adults inhabiting the reef. Second, habitats within the bay and on the reef are connected through ontogenetic migrations of certain fishes from their juvenile to their adult habitats. Third, for some species of reef fishes this linkage results in the propagation of year-class strength of bay populations to adjacent reef populations 1 or $2 \mathrm{yr}$ later. Fourth, this congruence of year-class strength among bay and reef populations is indicative of the nursery role of mangroves and annual population replenishment. Since there are demonstrable longterm linkages between inshore mangrove nurseries with adult habitats on adjacent reefs, 'reef-centric' habitat and fishery conservation measures that fail to include mangrove resources are likely to be ineffective.
Acknowledgements. This research was carried out under the auspices of the Cooperative Institute for Marine \& Atmospheric Studies (CIMAS) of the University of Miami's Rosenstiel School under cooperative agreement \#NA17RJ1226 with the National Oceanic and Atmospheric Administration (NOAA). This work was funded by a grant from the NOAA Coral Reef Conservation Program. We thank S. Smith and D. Harper for access to and assistance with the reef fishes database and C. Faunce and B. Teare for their assistance in data collection and processing. The views expressed herein are those of the authors and do not necessarily represent the views of NOAA or its sub-agencies.

\section{LITERATURE CITED}

Adams AJ, Ebersole JP (2002) Use of back-reef and lagoon habitats by coral reef fishes. Mar Ecol Prog Ser 228: $213-226$

Adams AJ, Dahlgren CP, Kellison GT, Kendall MS and others (2006) Nursery function of tropical back-reef systems. Mar Ecol Prog Ser 318:287-301

Anderson MJ (2001) Permutation tests for univariate or multivariate analysis of variance and regression. Can J Fish Aquat Sci 58:626-639

Ault JS, Bohnsack JA, Meester GA (1998) A retrospective (1979-1996) multispecies assessment of coral reef fish stocks in the Florida Keys. Fishery Bulletin 96:395-414

Ault JS, Diaz GA, Smith SG, Luo J, Serafy JE (1999) An efficient sampling survey design to estimate pink shrimp population abundance in Biscayne Bay, Florida. N Am J Fish Manag 19:696-712

Austin HM (1971) A survey of ichthyofauna of the mangroves of western Puerto Rico during December, 1967-August, 1968. Caribb J Sci 11:27-39

> Beck MW, Heck KL Jr, Able KW, Childers DL and others (2001) The identification, conservation, and management of estuarine and marine nurseries for fish and invertebrates. Bioscience 51:633-641

Berkeley SA, Campos WL (1984) Fisheries assessment of Biscayne Bay. Final Report to Dade County Department of Environmental Research Management, Miami, FL

Berkeley SA, Pybas DW, Campos WL (1985) Bait shrimp fishery of Biscayne Bay. Florida Sea Grant Technical Paper 40: $1-16$

Blaber SJM (2000) Tropical estuarine fishes: ecology, exploitation and conservation. Fish and Aquatic Resources Series 7. Blackwell Science, Oxford

Bohnsack JA, Ault JS (1996) Management strategies to conserve marine biodiversity. Oceanography 9:73-82

Bohnsack JA, Bannerot SP (1986) A stationary visual census technique for qualitatively assessing community structure of coral reef fishes. NOAA Tech Rep NMFS 41:1-41

Bohnsack JA, McClellan DB, Harper DE, Davenport GS and others (1999) Baseline data for evaluating reef fish populations in the Florida Keys, 1979-1998. NOAA Tech Memo NMFS-SEFSC-427

Browder JA, Yeung C, Schmidt T, Butler MJ and others (2007) Higher-trophic-level species. In: Hunt J, Nuttle W (eds) Florida Bay science program: a synthesis of research on Florida Bay. FWRI Technical Report TR-11. Florida Fish and Wildlife Conservation Commission, St. Petersburg, FL, p 110-148

$>$ Browder J, Ogden JC (1999) The natural South Florida system. II. Predrainage ecology. Urban Ecosyst 3:245-277

> Caldow C, Wellington GM (2003) Patterns of annual increment formation in otoliths of pomacentrids in the tropical 
western Atlantic: implications for population age-structure examination. Mar Ecol Prog Ser 265:185-195

Chittaro PM, Fryer BJ, Sale PF (2004) Discrimination of French grunts (Haemulon flavolineatum, Desmarest, 1823) from mangrove and coral reef habitats using otolith microchemistry. J Exp Mar Biol Ecol 308:169-183

Claro R, García-Arteaga JP (2001) Growth patterns of fishes of the Cuban Shelf. In: Claro R, Lindeman KC, Parenti LR (eds) Ecology of the marine fishes of Cuba. Smithsonian Institution Press, Washington, DC, p 149-178

Claro R, Lindeman KC, Parenti LR (eds) (2001) Ecology of the marine fishes of Cuba. Smithsonian Institution Press, Washington, DC

> Cocheret de la Morinière E, Pollux BJA, Nagelkerken I, van der Velde G (2003) Diet shifts of Caribbean grunts (Haemulidae) and snappers (Lutjanidae) and the relation with nursery-to-coral reef migrations. Estuar Coast Shelf Sci 57:1079-1089

Croker RA (1962) Growth and food of the gray snapper, Lutjanus griseus, in Everglades National Park. Trans Am Fish Soc 91:379-383

de Sylva DP (1963) Systematics and life history of the great barracuda Sphyraena barracuda Walbaum. Stud Trop Oceanogr Miami 1. University of Miami Press, Coral Gables, FL

de Sylva DP (1976) Fishes of Biscayne Bay, Florida. In: Thorhaug A, Volker A (eds) Biscayne Bay: past/present/ future. Papers presented for Biscayne Bay Symposium I. University of Miami Sea Grant Program, Coral Gables, FL, p 181-202

Dennis GD (1988) Commercial catch length-frequency data as a tool for fisheries management with an application to the Puerto Rico trap fishery. Mem Soc Cienc Nat La Salle 48(suppl 3):289-310

> Dorenbosch M, Grol MGG, Christianen MJA, Nagelkerken I, van der Velde G (2005) Indo-Pacific seagrass beds and mangroves contribute to fish density and diversity on adjacent coral reefs. Mar Ecol Prog Ser 302:63-76

> Dorenbosch M, Grol MGG, Nagelkerken I, van der Velde G (2006) Seagrass beds and mangroves as potential nurseries for the threatened Indo-Pacific humphead wrasse, Cheilinus undulatus and Caribbean rainbow parrotfish, Scarus guacamaia. Biol Conserv 129:277-282

> Dorenbosch M, Verbeck WCEP, Nagelkerken I, van der Velde G (2007) Influence of habitat configuration on connectivity between fish assemblages of Caribbean seagrass beds, mangroves and coral reefs. Mar Ecol Prog Ser 334: 103-116

Dustan P, Hallas JC (1987) Changes in reef-coral community of Carysfort Reef, Key Largo, Florida - 1974-1982. Coral Reefs 6:91-106

Faunce C, Serafy JE (2007) Nearshore habitat use by gray snapper (Lutjanus griseus) and bluestriped grunt (Haemulon sciurus): environmental gradients and ontogenetic shifts. Bull Mar Sci 80:473-495

Faunce CH, Serafy JE (2008) Selective use of mangrove shorelines by snappers, grunts, and great barracuda. Mar Ecol Prog Ser 356:153-162

Froese R, Binohlan C (2000) Empirical relationships to estimate asymptotic length, length at first maturity and length at maximum yield per recruit in fishes, with a simple method to evaluate length frequency data. J Fish Biol 56: 758-773

Froese R, Pauly D (eds) (2008) FishBase. www.fishbase.org (accessed 09/2008)

Halpern BS (2004) Are mangroves a limiting resource for two coral reef fishes? Mar Ecol Prog Ser 272:93-98
Hixon MA (1991) Predation as a process structuring coral reef fish communities. In: Sale PF (ed) The ecology of fishes on coral reefs. Academic Press, San Diego, CA, p 475-508

IUCN (2008) International union for conservation of nature and natural resources red list of threatened species, available at www.redlist.org

Jones DL (2002) Users manual for Fathom: a Matlab toolbox for multivariate ecological and oceanographic data analysis. Cooperative Institute for Marine and Atmospheric Science, University of Miami-RSMAS, Coral Gables, FL, available at www.rsmas.miami.edu/personal/djones/

- Laegdsgaard P, Johnson C (2001) Why do juvenile fish utilize mangrove habitats? J Exp Mar Biol Ecol 257:229-252

Lassen H (1988) Splitting length distributions into peaks and the clean class concept. Fishbyte 6:11-14

Ley JA, McIvor CC (2002) Linkages between estuarine and reef fish assemblages: enhancement by the presence of well-developed mangrove shorelines. In: Porter JW, Porter KG (eds) The Everglades, Florida Bay, and coral reefs of the Florida Keys. CRC Press, Boca Raton, FL, p 343-360

- Ley JA, McIvor CC, Montague CL (1999) Fishes in mangrove prop-root habitats of northeastern Florida Bay: distinct assemblages across an estuarine gradient. Estuar Coast Shelf Sci 48:701-723

> Luo J, Serafy JE, Sponaugle S, Teare PB, Kieckbusch D (2009) Movement of gray snapper Lutjanus griseus among subtropical seagrass, mangrove, and coral reef habitats. Mar Ecol Prog Ser 380:255-269

Martinez-Andrade F (2003) A comparison of life histories and ecological aspects among snappers (PISCES: Lutjanidae). $\mathrm{PhD}$ thesis, Louisiana State University

McArdle BH, Anderson MJ (2001) Fitting multivariate models to community data: a comment on distance-based redundancy analysis. Ecology 82:290-297

McCune B, Grace JB, Urban DL (2002) Analysis of ecological communities. MjM software design, Gleneden Beach, OR

Meester GA, Ault JA, Bohnsack JA (1999) Visual censusing and the extraction of average length as an indicator of stock health. Naturalista Siciliano 23:205-222

Mumby PJ (2006) Connectivity of reef fish between mangroves and coral reefs: algorithms for the design of marine reserves at seascape scales. Biol Conserv 128:215-222

> Mumby PJ, Edwards AJ, Arias-Gonzalez JE, Lindeman KC and others (2004) Mangroves enhance the biomass of coral reef fish communities in the Caribbean. Nature 427: 533-536

Nagelkerken I (2007) Are non-estuarine mangroves connected to coral reefs through fish migration? Bull Mar Sci 80:595-607

Nagelkerken I, van der Velde G (2002) Do non-estuarine mangroves harbour higher densities of juvenile fish than adjacent shallow-water and coral reef habitats in Curaçao (Netherland Antilles)? Mar Ecol Prog Ser 245:191-204

> Nagelkerken I, Dorenbosch M, Verberk WCEP, Cocheret de la Moriniere E, van der Velde G (2000a) Importance of shallow-water biotopes of a Caribbean bay for juvenile coral reef fishes: patterns in biotope association, community structure and spatial distribution. Mar Ecol Prog Ser 202:175-192

Nagelkerken I, van der Velde G, Gorissen MW, Meijer GJ, van't Hof T, den Hartog C (2000b) Importance of mangroves, seagrass beds and the shallow coral reef as a nursery for important coral reef fishes, using a visual census technique. Estuar Coast Shelf Sci 51:31-44

> Nagelkerken I, Kleijnen S, Klop T, van den Brand RACJ, Cocheret de la Moriniere E, van der Velde G (2001) Dependence of Caribbean reef fishes on mangroves and 
seagrass beds as nursery habitats: a comparison of fish faunas between bays with and without mangroves/seagrass beds. Mar Ecol Prog Ser 214:225-235

> Nagelkerken I, Roberts CM, van der Velde G, van Riel MC, Cocheret de la Moriniere E, Nienhuis PH (2002) How important are mangroves and seagrass beds for coral-reef fish? The nursery hypothesis tested on an island scale. Mar Ecol Prog Ser 244:299-305

Nakamura Y, Sano M (2004) Overlaps in habitat use of fishes between a seagrass bed and adjacent coral and sand areas at Amitori Bay, Iriomote Island, Japan: importance of the seagrass bed as juvenile habitat. Fish Sci 70:788-803

Nakamura Y, Horinouchi M, Shibuno T, Tanaka Y and others (2008) Evidence of ontogenetic migration from mangroves to coral reefs by black-tail snapper Lutjanus fulvus: stable isotope approach. Mar Ecol Prog Ser 355:257-266

Odum WE, Heald EJ (1972) Trophic analyses of an estuarine mangrove community. Bull Mar Sci 22:671-738

Ogden JC, Gladfelter EH (eds) (1983) Coral reefs, seagrass beds, and mangroves: their interaction in the coastal zones of the Caribbean. UNESCO Reports in Marine Science 23

Parrish JD (1989) Fish communities of interacting shallowwater habitats in tropical oceanic regions. Mar Ecol Prog Ser 58:143-160

Pauly D (1978) A preliminary compilation of fish length growth parameters. Ber Inst Meereskd ChristianAlbrechts-Univ Kiel 55:1-200

Pauly D (1980) On the interrelationships between natural mortality, growth parameters, and mean environmental temperature in 175 fish stocks. J Cons Int Explor Mer 39: 175-192

Petraitis PS, Beaupre SJ, Dunham AE (2001) ANCOVA: nonparametric and randomization approaches. In: Scheiner SM, Gurevitch J (eds) Design and analysis of ecological experiments. Oxford University Press, New York, p 116-133

Pittman SJ, McAlpine CA (2003) Movements of marine fish and decapod crustaceans: process, theory and application. Adv Mar Biol 44:205-294

Porter JW, Meier OW (1992) Quantification of loss and change in Floridian reef coral populations. Am Zool 32:625-640

Randall JE (1967) Food habits of reef fishes of the West Indies. Stud Trop Oceanogr 5:665-847

Roberts CM (1996) Settlement and beyond: population regulation and community structure of reef fishes. In: Polunin NVC, Roberts CM (eds) Reef fisheries. Chapman \& Hall, London, p 85-112

Robertson AI, Duke NC (1987) Mangrove as nursery sites: comparisons of the abundance and species composition of fish and crustaceans in mangroves and other nearshore habitats in tropical Australia. Mar Biol 96:193-205
Rooker JR, Dennis GD (1991) Diel, lunar, and seasonal changes in a mangrove fish assemblage off southwestern Puerto Rico. Bull Mar Sci 49:881-894

Rutherford ES, Tilmant JT, Thue EB, Schmidt TW (1989) Fishery harvest and population dynamics of gray snapper, Lutjanus griseus, in Florida Bay and adjacent waters. Bull Mar Sci 44:139-154

Schwamborn SHL, Ferreira BP (2002) Age structure and growth of the dusky damselfish, Stegastes fuscus, from Tamandare reef, Pernambuco, Brazil. Environ Biol Fishes 63:79-88

Sedberry GR, Carter J (1993) The fish community of a shallow tropical lagoon in Belize, Central America. Estuaries 16: 198-215

Serafy JE, Lindeman KC, Hopkins TE, Ault JS (1997) Effects of freshwater canal discharge on fish assemblages in a subtropical bay: field and laboratory observations. Mar Ecol Prog Ser 160:161-172

Serafy JE, Faunce CH, Lorenz JJ (2003) Mangrove shoreline fishes of Biscayne Bay, Florida. Bull Mar Sci 72:161-180

Serafy JE, Valle M, Faunce CH, Luo J (2007) Species-specific patterns of fish abundance and size along a subtropical mangrove shoreline: an application of the delta approach. Bull Mar Sci 80:609-624

Shulman MJ (1985) Recruitment of coral reef fishes: effects of distribution of predators and shelter. Ecology 66: 1056-1066

Shulman MJ, Ogden JC (1987) What controls tropical reef fish populations: recruitment or benthic mortality? An example in the Caribbean reef fish Haemulon flavolineatum. Mar Ecol Prog Ser 39:233-242

Starck WA II (1970) Investigations on the gray snapper, Lutjanus griseus. Stud Trop Oceanogr 10:11-150

Tabb DC, Drummond B, Kenny N (1974) Coastal marshes of southern Florida as habitat for fishes and effects of changes in water supply on these habitats. Final Report to US Dept of Interior, Bureau of Sport Fisheries and Wildlife, Branch of River Basins, Rosenstiel School of Marine and Atmospheric Science, University of Miami, Miami, FL

Thayer GW, Colby DR, Hettler WF Jr (1987) Utilization of the red mangrove prop root habitat by fishes in south Florida. Mar Ecol Prog Ser 35:25-38

Unsworth RKF, Salinas De Leon P, Garrard S, Jompa J, Smith DJ, Bell JJ (2008) High connectivity of Indo-Pacific seagrass fish assemblages with mangrove and coral reef habitats. Mar Ecol Prog Ser 353:213-224

Verweij MC, Nagelkerken I, Hol KEM, van den Beld AHJB, ven der Velde G (2007) Space use of Lutjanus apodus including movement between a putative nursery and a coral reef. Bull Mar Sci 81:127-138

Winer B (1971) Statistical principles in experimental design. McGraw-Hill, New York 
Appendix 1. Abudefduf saxatilis, Haemulon parra, Lutjanus spp., and Sphyraena barracuda. Statistical significance (permutation-based p-values) of pair-wise correlations calculated for abundance indices for age- 0 and age- 1 fishes from leeward key mangrove (LK), mainland mangrove (ML), or offshore reef (RF) habitats vs. lagged indices from age 0 to $4+$ reef fishes (LRF); only those comparisons yielding significant ( $\alpha=0.05,1000$ permutations), positive correlations are shown $\left(^{*}\right)$

\begin{tabular}{|c|c|c|c|c|c|c|}
\hline \multirow{2}{*}{ LRF: } & \multicolumn{3}{|c|}{ Age 0} & \multirow[b]{2}{*}{ LK } & \multirow{2}{*}{$\begin{array}{c}\text { Age } 1 \\
\text { ML }\end{array}$} & \multirow{2}{*}{$\mathrm{RF}$} \\
\hline & LK & ML & $\mathrm{RF}$ & & & \\
\hline \multicolumn{7}{|c|}{ Abudefduf saxatilis } \\
\hline Age 1 & $0.049^{*}$ & - & - & - & - & - \\
\hline Age 3 & - & - & - & $0.024^{*}$ & - & - \\
\hline \multicolumn{7}{|c|}{ Haemulon parra } \\
\hline Age 1 & - & - & $0.024^{*}$ & - & - & - \\
\hline \multicolumn{7}{|c|}{ Lutjanus apodus } \\
\hline Age 2 & - & - & - & $0.007^{*}$ & - & - \\
\hline Age 3 & - & $0.047^{*}$ & - & - & - & - \\
\hline \multicolumn{7}{|c|}{ Lutjanus griseus } \\
\hline Age 2 & - & - & - & $0.040^{*}$ & - & - \\
\hline \multicolumn{7}{|c|}{ Sphyraena barracuda } \\
\hline Age 3 & - & - & - & $0.012^{*}$ & - & - \\
\hline
\end{tabular}

Editorial responsibility: Ivan Nagelkerken, Nijmegen, Netherlands
Submitted: May 20, 2009; Accepted: November 5, 2009 Proofs received from author(s): February 8, 2010 